\title{
Effect of selenium on growth and physiological traits of basil plant (Ocimum basilicum L.) under arsenic stress conditions
}

\author{
Mahdi Rostami ${ }^{1}$, Hossein Abbaspour ${ }^{1}$ \\ ${ }^{1}$ Department of Biology, Damghan Branch, Islamic Azad University, Damghan, Iran. E-mail: mahdirostami@ gmail.com, \\ H.Abbaspour@Damghaniau.ac.ir
}

Received: 22/01/2019; Accepted: 12/02/2019.

\begin{abstract}
Arsenic is one of the common toxins in the environment that enters the environment through natural and artificial sources and causes stress in plants through various ways, including the effect on growth and metabolism of the plant. Further, the absorbance of this element in plants and the entry into the food chain create toxicity for humans. On the other hand, Selenium is a non-biological stress reliever and has a considerable impact on improved plant growth and photosynthesis and reduced stress. Due to the interaction of Arsenic and Selenium in soil and different plants and the importance of Basil plant, an experiment was performed to investigate the effect of Selenium on growth and some physiological traits of Basil plant (Ocimum basilicum L.) under Arsenic stress conditions. To implement this plan, a factorial pot experiment was carried out based on a randomized complete block design with three replications in Damghan Islamic Azad University. Arsenic concentrations of 0, 100, 200 and 300 micromoles with irrigation water were applied three times at regular intervals and Selenium concentrations of 0, 2.5, 5 and 10 $\mathrm{mg} \mathrm{L}^{-1}$ were applied three times by solution spraying at regular intervals. In this experiment, it was found that growth traits decreased by increasing Arsenic. The lowest performance was related to Arsenic concentration of 300 $\mu \mathrm{m}$, resulting in a $45 \%$ decrease in growth and by applying Selenium treatment, Arsenic toxicity effect was reduced. The best performance was associated with Selenium concentration of $5 \mathrm{mg} \mathrm{L}^{-1}$.
\end{abstract}

Keywords: traits, Ocimum basilicum L., arsenic stress, photosynthetic pigments.

\section{Efeito do selênio no crescimento e nas características fisiológicas de manjericão (Ocimum basilicum L.) sob condições de estresse por arsênio}

\section{RESUMO}

O arsênio é uma das toxinas comuns no ambiente e, ao entra neste, seja por fontes naturais ou artificiais, causa estresse nas plantas por meio de várias formas, incluindo o efeito no crescimento e metabolismo da planta. Além disso, a absorção deste elemento pelas plantas e a entrada na cadeia alimentar criam toxicidade para os seres humanos. Por outro lado, o selênio é um elemento não-biológico para aliviar o estresse e tem um impacto considerável no crescimento das plantas e na fotossíntese, além de reduzir o estresse. Devido à interação de Arsênio e Selênio no solo com diferentes plantas e a importância do manjericão, um experimento foi realizado para investigar o efeito do selênio sobre o crescimento e características fisiológicas da planta de manjericão (Ocimum basilicum L.) sob condições de estresse por arsênio. Para conduzir este estudo, um experimento em esquema fatorial foi realizado com delineamento em blocos casualizados com três repetições, na Universidade Damghan Islamic Azad. Concentrações de arsênio de 0, 100, 200 e 300 micromoles com água de irrigação foram aplicadas

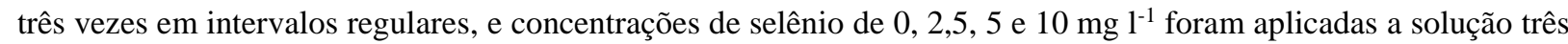
vezes por pulverização, em intervalos regulares. Neste experimento, verificou-se que as características de crescimento diminuíram com o aumento de arsênio. $\mathrm{O}$ menor desempenho foi relacionado à concentração de arsênio de $300 \mu \mathrm{m}$, resultando em uma redução de 45\% no crescimento e, aplicando o tratamento com selênio, o efeito da toxicidade do arsênio foi reduzido. $\mathrm{O}$ melhor desempenho foi associado à concentração de selênio de 5 $\mathrm{mg}^{-1}$.

Palavras-chave: características, Ocimum basilicum L., estresse por arsênio, pigmentos fotossintéticos. 


\section{Introduction}

Because of agricultural and industrial measures such as the use of insecticides and chemical fertilizers, irrigation with sewage, sediments from coal fuel, waste from metal smelting plants and metal mine residues, large areas of agricultural lands in the world have been infected with heavy metals (Zhang et al., 2002).

On the other hand, heavy metal pollution has become a growing concern due to intensive and excessive human activities in the last century. There is a lot of documentation about the damage of heavy metals to plants' absorption, such as cadmium (Kumar et al., 2012), arsenic (Malik et al., 2012), lead (MroczekZdyrska and Wojcik, 2012), aluminum (Cartes et al., 2010) and antimony (Feng et al., 2012).

One of the most dangerous heavy metals that have attracted the attention of many researchers today and has harmful effects on human health is arsenic. Arsenic as a quasi-metal is considered an unnecessary element for plants and has no application in physiological and metabolic systems of the plant (Tu and Ma, 2003).

Arsenate as a compound similar to phosphorus enters the plant through phosphate carriers and thus reduces the absorption of phosphorus by the plant while arsenite is introduced into the roots of plants through aquaglyceroporins. Arsenic stops the phosphate absorption system with high affinity in the cell membrane and disrupts the energy flow of cells (Garg and Singla, 2011). Numerous studies have indicated that arsenic induces toxicity in plants, inhibits growth and ultimately leads to the death of the plant (Garg and Singla, 2011; Gupta et al., 2009).

Research shows that the use of elements with antioxidant properties to improve growth and reduce the destructive effects of heavy metal stresses can be very beneficial (Turakainen et al., 2004). Selenium plays an important role in neutralizing abiotic stresses in plants, which have been created due to cold, drought, intense light, heavy metals, water, salinity, uv-b and high temperatures (Feng et al., 2012).

Desirable selenium use could increase the antioxidant potential of deciduous plants and the delay in the aging of lettuce, rye and soya and improve potato under cold stress and raise salinity resistance in the seedling of a kind of oxalis (Djanaguiraman et al., 2005).

Because of the importance of selenium in the diet, the world food organization considers as necessary the inclusion of selenium in plant products, such as wheat, barley, rice and potato (Tamás et al., 2010).

Since O. basilicum L. is one of the most economical species belonging to the mint family and is planted around the world (Labra et al., 2004), its optimal and appropriate growth is very important. Accordingly, this study has been conducted to identify the effects of selenium on growth and some physiological traits of basil plant under arsenic stress conditions.

\section{Material and Methods}

In order to examine the impact of Selenium on Basil plant (Ocimum basilicum L.) in Arsenic stress conditions, a factorial pot experiment was carried out based on a randomized complete block design with three replications as follows. In this experiment, Selenium concentration in four levels $(0,2.5,5$ and 10 $\mathrm{mg} \mathrm{l}^{-1}$ ) from the source of Selenate and Arsenic concentration in four levels $(0,100,200$ and 300 micromoles) from the source of Arsenat were used. All the materials with analytical purity were prepared from the Merck Plant.

Basil plant seeds were first washed with water and were then disinfected in 10\% sodium hypochlorite solution for 10 minutes. Afterwards, they were washed twice with distilled water. After that, the seeds were soaked in distilled water for 24 hours and were cultivated in pots with a diameter of $8 \mathrm{~cm}$ and a height of $15 \mathrm{~cm}$ filled with soft and disinfected gravel. During the growth period, the temperature in the light-dark period was $16-25$. The light period was 16 hours and the dark period lasted for 8 hours. After ensuring germination and plant growth, the number of plants in each pot was reduced to 10 in the four-leaf stage. Irrigation was carried out every three days as needed by the plant and during the plant growth until the four-leaf stage, the plant was irrigated once a week with Hoagland (Hoagland and Arnon, 2012) in order to grow better and provide nutritional needs. After the plant became four-leaf, different concentrations of arsenic were used three times along with irrigation water at regular intervals and different concentrations of selenium were also applied three times by solution spraying at regular intervals along with arsenic treatment until the end of plant harvest.

Plants were collected four weeks after applying arsenic treatment and after harvesting, they were transferred to a freezer of -80 to measure the desired traits. After the harvest, the roots were removed from the stem with a razor and then, shoot and root lengths and weights were measured by a scale with the accuracy of 0.001 gr. chlorophyll a and b content (Lichtenthaler, 1987) was measured. 0.1 gram of leaf was pulverized with $4 \mathrm{ml}$ of $80 \%$ acetone in a mortar. Afterwards, the obtained solution was centrifuged at $3000 \mathrm{rpm}$ for 5 minutes and absorbance of the supernatant was read to determine the amount of chlorophyll $\mathrm{a}$ and $\mathrm{b}$ and carotenoids by the spectrophotometer at 647 and 664 $\mathrm{nm}$ wavelengths. To make the device zero, $80 \%$ acetone was used. To calculate chlorophyll a and $\mathrm{b}$ content, the following formulas were applied. The absorbance of the 
solution at 645 and $663 \mathrm{~nm}$ wavelengths was read and calculated by the spectrophotometer using $80 \%$ acetone control.

$$
\left[12.25\left(A_{644}\right)-2.79\left(A_{647}\right)\right] \times \frac{V}{1000 \times W}=\text { mg chlorophyll }
$$

a per $\mathrm{g}$ fresh weight

$$
\left[21.51\left(A_{647}\right)-5.1\left(A_{664}\right)\right] \times \frac{V}{1000 \times W}=\text { mg chlorophyll b }
$$

per $g$ fresh weight

$\mathrm{V}=$ The volume of extracted chlorophyll in $\mathrm{ml}$

$\mathrm{W}=$ The fresh weight of the tissue used in gr

Data analysis was done by SPSS software using Duncan method and charts were also drawn by EXL software.

\section{Results and Discussion}

\subsection{Growth traits}

Arsenic treatments, especially $300 \mu \mathrm{m}$ Arsenic treatment, reduced the growth of Basil plant by $44 \%$. In Arsenic stress conditions, by applying incremental treatment of Selenium, the length of Basil shoot also showed a significant increase $(\alpha \leq 0.01)$ compared to the control sample (Table 1) so that we had a $38 \%$ increase in growth compared to the control treatment. But by increasing the Selenium concentration to $10 \mathrm{mg}$ $1^{-1}$, growth declined again, resulting in a $20 \%$ decrease in growth relative to other Selenium treatments (Figure 1).

Study of means suggested that Arsenic treatments up to the concentration of 200 micromoles increased the length of Basil root by $21 \%$. But in the concentration of 300 micromoles, it had a $27 \%$ decrease in growth compared to the best concentration. In Arsenic stress conditions, Selenium made a significant impact $(\alpha \leq$ 0.01) on the length of Basil root (Table 1). The root length, unlike shoot, increased with an increase in Selenium in low concentrations of Arsenic. But with increasing Arsenic concentration, the best performance was related to Selenium concentration of $5 \mathrm{mg} \mathrm{l}^{-1}$ and in the treatment of $300 \mathrm{Mm}$ of Arsenic, the root length increased by $37 \%$ (Figure 1).

Comparison of average data indicates that the effect of Arsenic and Selenium on fresh weight of Basil shoot was significant $(\alpha \leq 0.05)$ (Table 1$)$ so that with increased Selenium in Arsenic stress, shoot weight also increased and at a concentration of $300 \mu 1$ with a spray of $5 \mathrm{mg} / \mathrm{l}$, performance increased by $40 \%$ (Figure 2). But by increasing Selenium to $10 \mathrm{mg} \mathrm{l}^{-1}$, a negative effect appeared and Basil shoot weight was reduced by $63 \%$ compared to the best treatment and the best performance in low Arsenic concentrations was related to Selenium concentration of $5 \mathrm{mg} \mathrm{l}^{-1}$ and in high Arsenic concentrations, the best performance was obtained from Selenium concentration of $2.5 \mathrm{mg} \mathrm{l}^{-1}$ (Figure 2).

Unlike shoot weight, root weight increased by Arsenic treatment so that with $200 \mu \mathrm{m}$ Arsenic treatment, root weight increased by $29 \%$ relative to the control sample although it again decreased by increasing Arsenic to 300 micromoles (Figure 2). Study of average data demonstrated that the effect of Arsenic and Selenium on Basil root fresh weight was significant ( $\alpha \leq 0.01$ ) (Table 3-1). Shoot weight and root weight showed different behaviors in relation to the impact of Selenium on Arsenic stress. With increased Selenium, root weight decreased in most of Arsenic concentrations (Figure 2).

Table 1. Comparison of average data related to the effect of Arsenic and Selenium on Basil plant

\begin{tabular}{llllllll}
\hline Factor of & Df & Root length & Shoot & Root & Shoot & Chlorophyll a & Chlorophyll b \\
\hline Selenium (Se) & 3 & $70.656 \mathrm{~ns}$ & $14.0023 * *$ & $0.00943 * *$ & $0.00684 * *$ & $2.74814 * *$ & $1.26880^{* *}$ \\
Arsenic (Ar) & 3 & $8.7250 * *$ & $6.5689 * *$ & $0.00667 * *$ & $0.04923 \mathrm{~ns}$ & $0.84399 * *$ & $0.91740^{* *}$ \\
Se x Ar & 9 & $4.2362 * *$ & $1.3088^{* *} *$ & $0.00229 * *$ & $0.01671 *$ & $0.26248 * *$ & $0.04498^{* *}$ \\
Error & & 23.2346 & 0.3573 & 0.00028 & 0.00714 & 0.02405 & 0.00682 \\
\hline
\end{tabular}

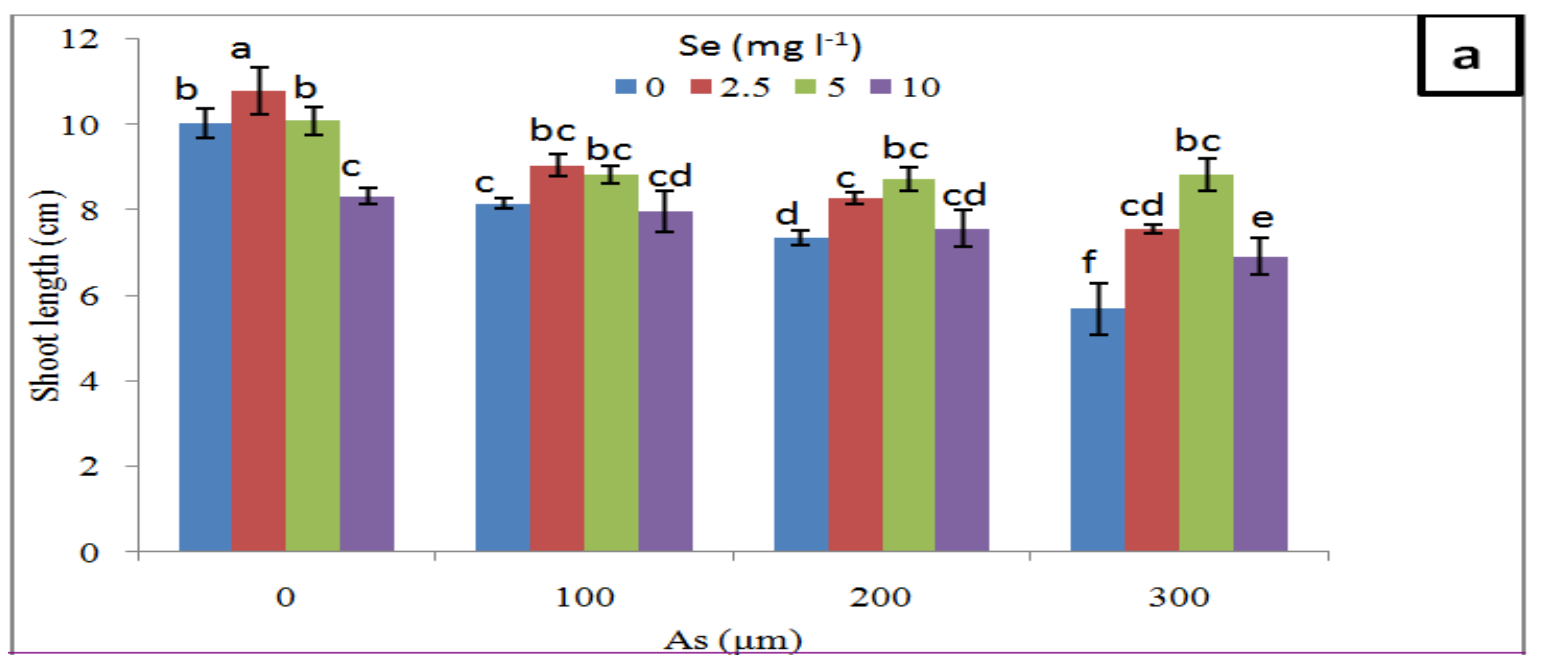




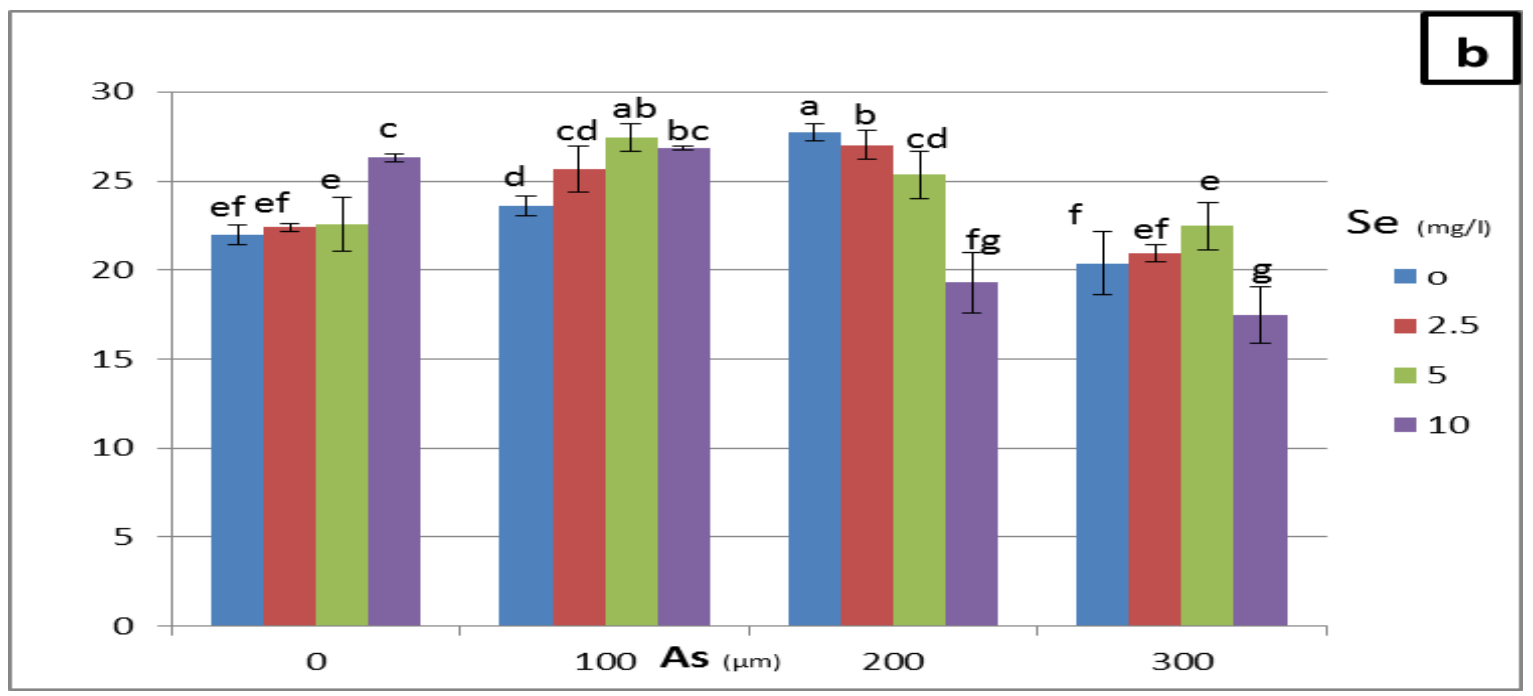

Figure 1. Effect of Arsenic and Selenium on Basil shoot (a) and root (b) length.
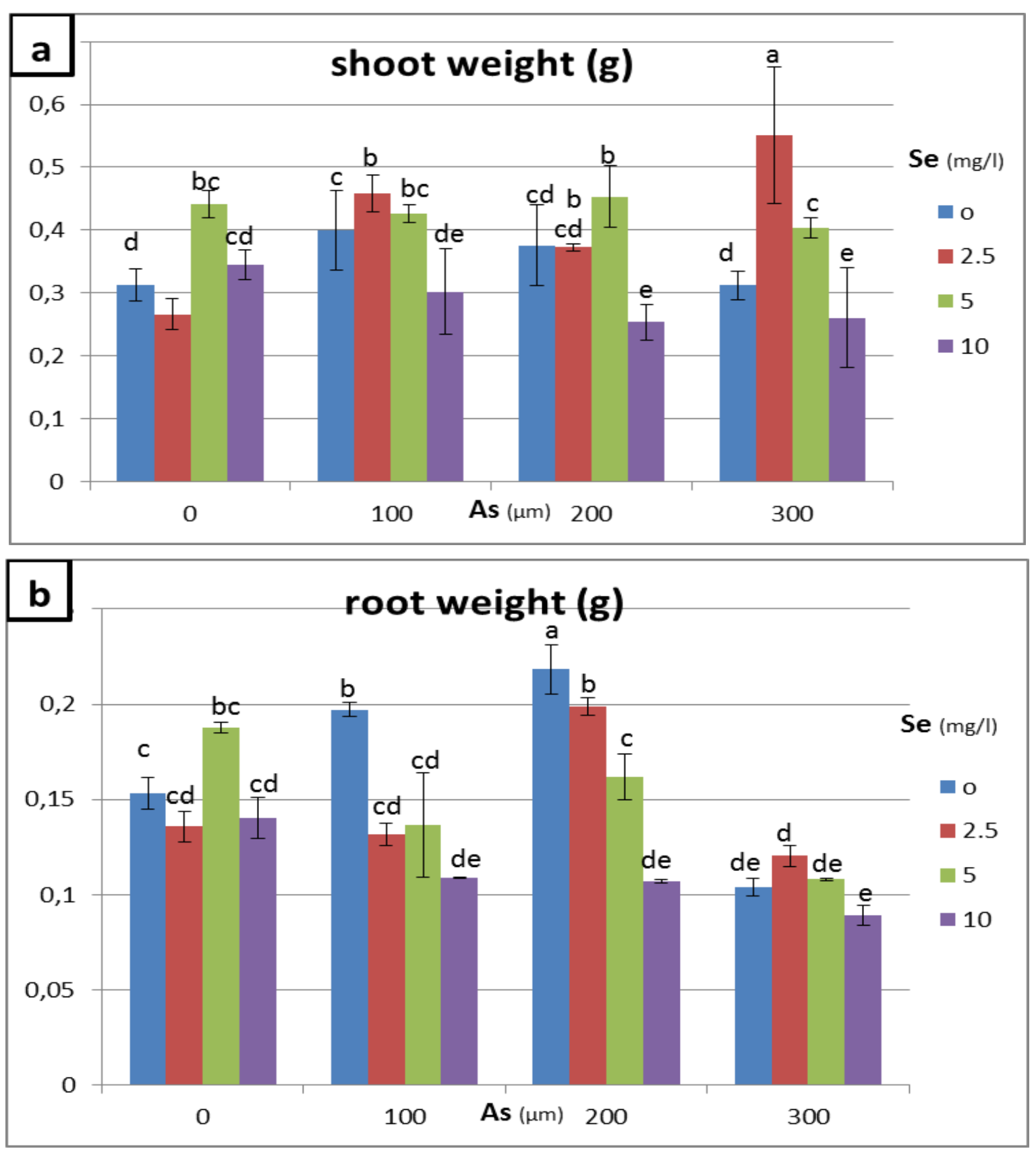

Figure 2. Effect of Arsenic and Selenium on Basil shoot (a) and root (b) length. 


\subsection{Photosynthetic pigments}

Arsenic treatment reduced chlorophyll a content by 3 times. Study of average data suggests that the effect of Arsenic and Selenium on chlorophyll a content of Basil plant was significant $(\alpha \leq 0.01)$ (Table 1). With increased Arsenic concentration, chlorophyll content decreased and in each Arsenic treatment, by spraying Selenium with a concentration of $5 \mathrm{mg} \mathrm{l}^{-1}$, the stress effect was reduced. But by increasing the concentration to $10 \mathrm{mg} \mathrm{l}^{-1}$, the effect of stress reduction decreased and chlorophyll content also decreased (Figure 3a) such that at $300 \mu \mathrm{m}$ Arsenic concentration, chlorophyll a content increased by more than twice by spraying $5 \mathrm{mg} \mathrm{l}^{-1}$ of
Selenium. But $10 \mathrm{mg} \mathrm{l}^{-1}$ Selenium concentration had $38 \%$ reduction compared to the best treatment (Figure 3a).

Comparison of average data shows that the effect of Arsenic and Selenium on chlorophyll $b$ content of Basil plant was significant $(\alpha \leq 0.01)$ (Table 1$)$. As can be observed in Figure 3b, by applying Arsenic treatment, Arsenic stress effect reduced chlorophyll $b$ content by more than twice and with Selenium spray, Arsenic stress decreased. In all Arsenic treatments, $5 \mathrm{mg} \mathrm{l}^{-1}$ Selenium treatment had the best performance so that at a concentration of $300 \mu$, this treatment resulted in a $60 \%$ increase in chlorophyll b content.
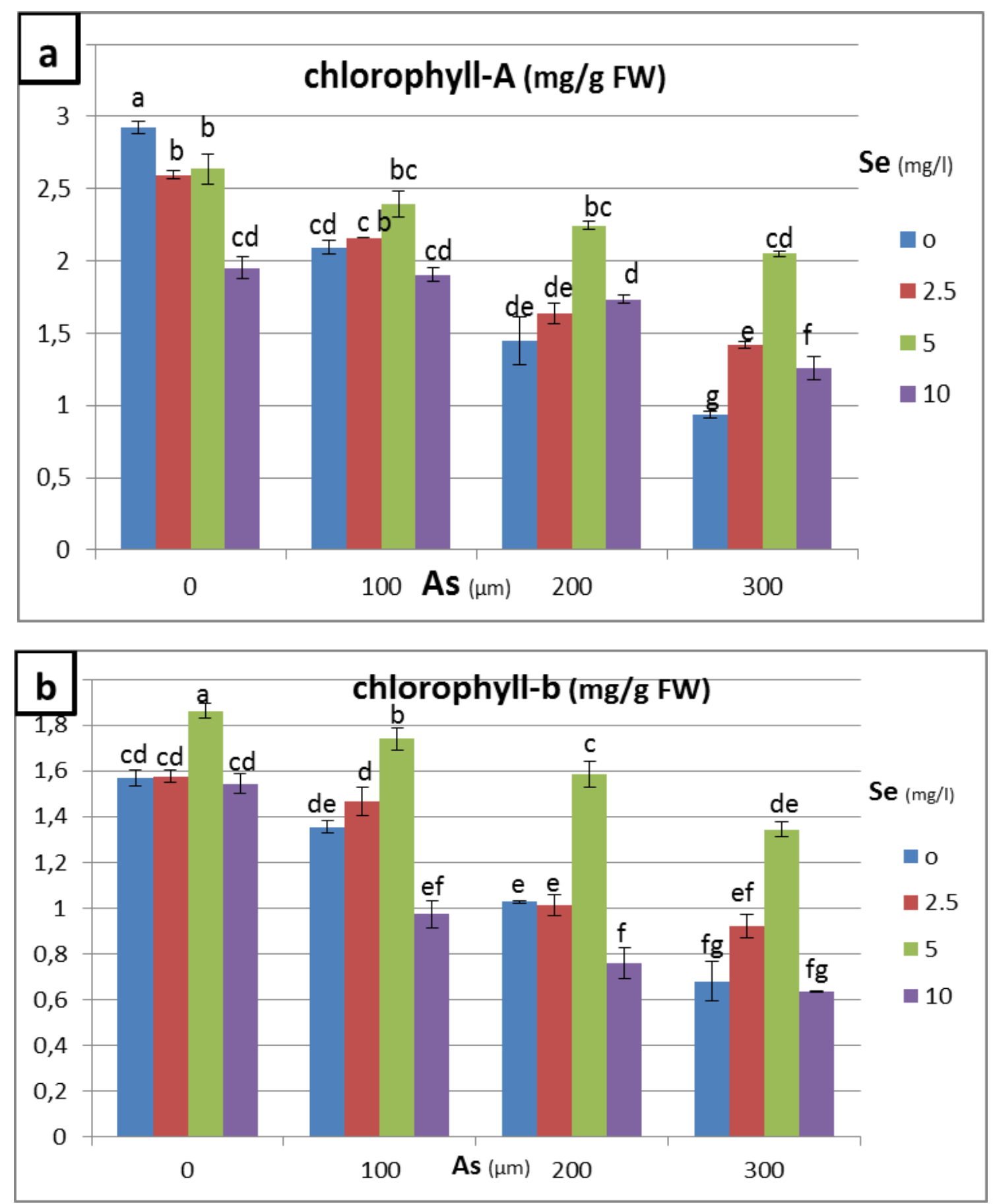

Figure 3. Effect of Arsenic and Selenium on the amount of photosynthetic pigments in Basil shoot (a) and root (b) length. 


\subsection{Growth traits}

In this study, it was demonstrated that Arsenic reduced basil plant growth and selenium had a positive effect on plant growth. In arsenic stress conditions, selenium could increase plant growth and reduce stress effects. Concerning the effects of arsenic and selenium, higher levels of selenium had negative effects on plant growth and the best performance was related to selenium concentration of $5 \mathrm{mg} \mathrm{l}^{-1}$.

Shaibur et al. (2006) reported that with arsenic consumption, growth and dry weight of leaf, stem and root of rice plant decreased. Moreover, in the studies conducted on wheat, it was determined that levels of arsenic reduced the growth and weight of wheat shoot and root (Pigna et al., 2009). In this research, it was also found that arsenic had a toxic effect on the growth of root and shoot of basil plant and with increased levels of arsenic, this effect was intensified. Pennanen showed that selenium treatment increased shoot length (Pennanen et al., 2006). Lower selenium concentrations increase plant growth due to increased photosynthetic pigments and enhanced carbon stabilization and also synthesis and hydrolysis of starch and sucrose. But in higher levels, reduced photosynthetic pigments and synthesis and thus decreased plant growth will be resulted (Han-Wens et al., 2010).

Photosynthesis restoration in plants under stress after application of selenium may be associated with reduced levels of reactive oxygen species (Paciolla et al., 2011). Additionally, with selenium application and antioxidant reactivity, the damaged structure of chloroplasts is restored and the production of other vital metabolites such as glutathione peroxidase (gsh-px) and pseudo-thiol (-sh) bodies increases (Filek et al., 2008). As a result, plant growth increases under stress conditions.

\subsection{Pigment traits}

Experiments have shown that with increased arsenic concentrations, the content of photosynthetic pigments decreased. Adding appropriate amounts of selenium led to increased rate of photosynthetic pigments. But with an increase in selenium levels to higher amounts (10 $\mathrm{mg} / \mathrm{l})$, negative effects appeared. In this study, with increased appropriate levels of selenium in simultaneous treatments of arsenic heavy metal, the content of chlorophyll and carotenoid increased and selenium could modify the toxic effects of arsenic.

Studies conducted on wheat and beans display that oxidative stress by arsenic causes chlorosis in these plants, leading to reduced chlorophyll content of leaves, deformation of chloroplast and destruction of carotenoid structures and hence reduced growth (Liu et al., 2008). Further, reduced total chlorophyll content and carotenoid during arsenic stress has been reported in corn (Stoeva et al., 2004), rice (Chun-xi et al., 2007) and sorghum, which is consistent with the results of this study. Arsenic has a concentration-dependent inhibitory effect on the synthesis of chlorophyll. This theory suggests that the chlorophyll synthesis and decomposition system is affected by high arsenic concentrations (Chun-xi et al., 2007).

Metal ion transport to the shoot and ultimately its accumulation in leaf cells cause morphological and physiological signs of stress in leaves, the most significant of which are leaf necrosis and chlorosis (Bergmann, 2004). When plants are exposed to environmental stresses and heavy metals, chloroplasts are destroyed and photosynthesis is directed towards rupture. In such cases, by adding appropriate levels of materials such as selenium, it is possible to partly prevent the destruction of chloroplasts and increase chlorophyll content (Filek et al., 2010). The use of selenium can cause to regulate reactive oxygen species (ROS) and antioxidants, prevent the adsorption and transfer of heavy metals, make changes in the characteristics of heavy metals, reconstruct the cell membrane and chloroplast structure and improve the photosynthetic system (Feng et al., 2012).

Research shows that treatment with low selenium concentrations increases biosynthesis of photosynthetic pigments by protecting the chloroplast enzymes (Pennanen et al., 2006). But with increased selenium concentration, this element inhibits chlorophyll biosynthesis enzymes (such as porphobilinogen synthase) and interacts with the sulfhydryl group in enzymes on 5-aminolevulinic acid dehydratase and porphobilinogen deaminase and in this way makes a negative impact on chlorophyll synthesis (Hawrylak et al., 2007). It seems that reduced chlorophyll content at higher levels of selenium is also related to reduced leaf lamina surface. Investigations carried out regarding the amount of chlorophyll in plants such as beans and lettuce and chlorella algae also showed similar results so that with increased selenium treatment concentration in chlorella algae, chlorophyll content decreased but the amount of xanthophyll and carotenoid increased (Chen et al., 2005). Germ et al. (2007) revealed that high levels of selenium has no effect on photosystem II and probably reduces the amount of photosynthesis in other ways. But low selenium concentrations increase the photochemical efficiency of photosystem II (Hasanuzzaman et al., 2010).

\section{Conclusions}

By applying Arsenic treatments, the growth rate of the plant shoot and root decreased and the effect of the heavy metal stress appeared. But by applying Selenium treatments, the stress effect was reduced and plant 
growth improved. Also, by increasing the level of Selenium to $10 \mathrm{mg} \mathrm{l}^{-1}$, a negative effect appeared which suggests that high concentrations of Selenium can have a negative impact. Photosynthetic pigments were also no exception and were reduced with increased Arsenic. Besides, the stress effect decreased by increasing Selenium and higher concentrations of Selenium were stressful and the best performance was related to Selenium concentration of $5 \mathrm{mg} \mathrm{l}^{-1}$.

\section{Bibliographic References}

Bergmann, D.C., 2004. Integrating signals in stomatal development. Current Opinion in Plant Biology, 7, 26-32.

Cartes, P., Jara, A.A., Pinilla, L., Rosas, A., Mora, M.L., 2010. Selenium improves the antioxidant ability against aluminiuminduced oxidative stress in ryegrass roots. Annals of Applied Biology, 156(2), 297-307.

Chen, T.F., Zheng, W.J., Luo, Y., Yang, F., Bai, Y., Tu, F., 2005. Effects of selenium stress on photosynthetic pigment contents and growth of Chlorella vulgaris. Journal of Plant Physiology and Molecular Biology, 31, 369-373.

Chun-xi, L., Shu-li, F., Yun, S., Li-na, J., Xu-yang, L., Xiao-li, H., 2007. Effects of arsenic on seed germination and physiological activities of wheat seedlings. Journal of Environmental Science, 19, 725-732.

Djanaguiraman, M., Devi, D.D., Shanker, A.K., Sheeba, J.A., Bangarusamy, U., 2005. Selenium - An antioxidative protectant in soybean during senescence. Plant Soil, 272(1-2), $77-86$.

Feng, R., Wei, C., Shuxin, T., 2012. The roles of selenium in protecting plant against abiotic stresses. Environmental and Experimental Botany, 98, 185-192.

Filek, M., Gzyl-Malcher, B., Zembala, M., Bednarska, E., Laggner, P., Kriechbaum, M., 2010. Effect of selenium on characteristics of rape chloroplasts modified by cadmium. Journal of Plant Physiology, 167(1), 28-33.

Filek, M., Keskinen, R., Hartikainen, H., Szarejko, I., Janiak, A., Miszalski, Z., Golda, A., 2008. The protective role of selenium in rape seedling subjected to cadmium stress. Journal of Plant Physiology, 165, 833-844.

Garg, N., Singla, P., 2011. Arsenic toxicity in crop plants: physiological effects and tolerance mechanisms. Environment Chemistry Letter, 9, 303-321.

Germ, M., Stibilj, V., Kreft, I., 2007. Metabolic importance of selenium for plants. The European Journal of Plant Science and Biotechnology, 1(1), 91-97.

Gupta, M., Sharma, P., Sarin, N.B., Sinha, A.K., 2009. Differential response of arsenic stress in two varieties of brassica juncea L. Chemosphere, 74, 1201-1208.
Han-Wens, S., Jing, H., Shu-Xuan, L., Wei-Jun, K., 2010. Protective role of selenium on garlic growth under cadmium stress. Communications in Soil Science and Plant Analysis, 41, 1195-1204.

Hasanuzzaman, M., Hossain, M.A., Fujita, M., 2010. Selenium in higher plants: physiological role, antioxidant metabolism and abiotic stress tolerance. Journal of Plant Science, 5, 354-375.

Hawrylak, B., Matraszek, R., Szynanska, M., 2007. Response of lettuce (Lactuca sativa L.) to selenium in nutrient solution contaminated with nickel. Vegetable Crops Research Bulletin, 67, 63-70.

Hoagland, D.R., Arnon, D.I., 2012. The water-method for growing plants without soil. Berkeley: University of California.

Kumar, M., Bijo, A.J., Baghel, R.S., Reddy, C.R.K., Jha, B., 2012. Selenium and Spermine alleviates cadmium induced toxicity in the red seaweed Gracilaria dura by regulating antioxidant system and DNA methylation. Plant Physiology and Biochemistry, 51, 129-138.

Labra, M., Miele, M., Ledda, B., Grassi, F., Mazzei, M., Sala, F., 2004. Morphological characterization, essential oil composition and DNA genotyping of Ocimum basilicum L. cultivars. Plant Science, 167, 725-731.

Lichtenthaler, H.K., 1987. Chlorophyll and carotenoids: pigments of photosynthetic biomembranes. Method Enzymol, $148,350-382$.

Liu, Q., Hu, C., Tan, Q., Sun, X., Su, J., Liang, Y., 2008. Effects of as on as uptake, speciation and nutrient by winter wheat (Triticum aestivum) under arsenate co-contamination. Ecotoxicology Environmental Safety, 68, 505-313.

Malik, J.A., Goel, S., Kaur, N., Sharma, S., Singh, I., Nayyar, H., 2012. Selenium antagonizes the toxic effects of arsenic on mungbean (Phaseolus aureus Roxb.) plants by restricting its uptake and enhancing the antioxidative and detoxification mechanisms. Environmental and Experimental Botany, 77, 242-248.

Mroczek-Zdyrska, M., Wójcik, M., 2012. The influence of selenium on root growthand oxidative stress induced by lead in Vicia faba L. minor plants. Biological Trace Element Research, 147, 320-328.

Paciolla, C., Leonardis, S., Dipierro, S., 2011. Effects of selenite and selenate on the antioxidant systems in Senecio scandens L. Plant Biosystology, 145, 253-259.

Pennanen, A., Xue, T., Hartikainen, H., Xue, T.L., 2006. Protective role of selenium in plant subjected to severe UV irradiation stress. J. Appl. Bot., 76, 66-76.

Pigna, M., Cozzolino, V., Violante, A., Meharg, A.A., 2009. Influence of phosphate on the arsenic uptake by wheat (Triticum durum L.) irrigated with arsenic solutions at three different concentrations. Water, Air and Soil Pollution, 197, 371-380. 
Shaibur, M.R., Kitajima, N., Sugawara, R., Kondo, T., Imamul Huq, S.M., Kawai, S., 2006. Physiological and mineralogical properties of arsenic-induced chlorosis in rice seedlings grown hydroponically. Soil Science and Plant Nutrition, 52, 691-700.

Stoeva, N., Berova, M., Zlatev, Z., 2004. Physiological response of maize to arsenic contamination. Planta, 47(3), 449-452.

Tamás, M., Mándoki, Z., Csapó, J., 2010. The role of selenium content of wheat in the human nutrition. Acta Univ. Sapientiae, Alimentaria, 3, 5-34.
Tu, C., Ma, L.Q., 2003. Effects of arsenate and phosphate on their accumulation by an arsenic hyperaccumulator Pteris vittata L. Plant Soil, 249, 373-382.

Turakainen, M., Hartikainen, H., Seppänen, M.M., 2004. Effects of selenium treatments on potato (Solanum tuberosum L.) growth and concentrations of soluble sugars and starch. Journal Agricalture Food Chemistry, 52, 5378-5382.

Zhang, J., Lu, E., Zhang, X.J., 2002. Study on the function and benefit of rice-duck agroecosystem. Ecology Science, 21(1), 6-10. 